\title{
Review
}

\section{Nitric oxide and vascular responses in Type I diabetes}

\author{
N. N. Chan ${ }^{1}$, P. Vallance ${ }^{2}$, H.M. Colhoun ${ }^{1}$ \\ ${ }^{1}$ EURODIAB Department of Epidemiology and Public-Health, University College London, UK \\ ${ }^{2}$ Department of Clinical Pharmacology, University College London, UK
}

\section{Abstract}

Vascular complications are major causes of morbidity and mortality in patients with diabetes mellitus. The mechanisms underlying the development of microvascular and macrovascular angiopathy in Type I (insulin-dependent) diabetes mellitus are complex and incompletely understood. The discovery of endothelium-derived nitric oxide has greatly improved our understanding of vascular biology. Nitric oxide has an important role in the regulation of vascular tone and impaired nitric oxide activity could be implicated in the development of diabetic vasculopathy. Vascular studies of endothelial function in Type I diabetes have produced conflicting results. The role of nitric oxide in diabetic vasculopathy is still not clear. [Diabetologia (2000) 43: 137-147]

Keywords Type I diabetes, nitric oxide, endothelium, vasodilatation, plethysmography, flow-mediated dilatation, vascular ultrasound.
Diabetic microangiopathy and macroangiopathy are the principal causes of morbidity and mortality in patients with diabetes mellitus [1-3]. Patients with Type I (insulin-dependent) diabetes mellitus have a three to sixfold increased risk of cardiovascular death before the age of 60 compared with non-diabetic subjects [4]. Established risk factors for coronary heart disease (CHD) do not, however, fully explain the increased risk in Type I diabetic patients [5].

The vascular endothelium has a key role in maintaining homeostasis of the vasculature through the synthesis of vasoactive substances that modulate vas-

Corresponding author: Dr. N. N. Chan, EURODIAB, Department of Epidemiology \& Public-Health, 1-19 Torrington Place, University College London, London WC1E 6BT, United Kingdom

Abbreviations: CHD, Coronary heart disease; NO, nitric oxide; STZ, streptozotocin; BM, basement membrane; VSMC, vascular smooth muscle cell; cGMP, cyclic guanosine monophosphate; L-NMMA, $N^{\mathrm{G}}$-monomethyl-L-arginine; NOS, nitric oxide synthase; SNP, sodium nitroprusside; FMD, flowmediated dilatation; $\mathrm{PKC}$, protein kinase $\mathrm{C}$; DAG, diacylglycerol; AGE, advanced glycation end product. cular tone, inhibit platelet aggregation and vascular smooth muscle cell (VSMC) proliferation $[6,7]$. Endothelial dysfunction has been suggested to be an early event in diabetic vascular disease $[8,9]$. The discovery of endothelium-derived nitric oxide (NO) in the late 1980s [10] has considerably improved our understanding in vascular biology and pathogenesis of endothelial dysfunction. With the use of techniques such as brachial artery ultrasonography, venous occlusion plethysmography and brachial artery infusion of endothelium-dependent vasoactive agents, endothelial function can be indirectly assessed in different vascular beds. Most published reviews have focused on Type II (non-insulin-dependent) diabetes mellitus rather than Type I diabetes. We reviewed the current evidence for endothelium-mediated vascular dysfunction in Type I diabetes following an extensive literature search from both Medline and PubMed (1965-1999) using the following keywords: 'Type I diabetes mellitus', 'endothelial function', 'nitric oxide', 'vasodilatation'. Potential mechanisms which could be involved in endothelial dysfunction in Type I diabetes are discussed. 


\section{Morphology of vasculature in diabetes}

The vascular endothelium forms the lining of the blood vessel wall separating the lumen from the vascular smooth muscle. Under the electron microscope, normal endothelial cells have a cobble-stone appearance with gap junction formation in between cells. A basement membrane separates this single layer of endothelial cells from the smooth muscle. Changes in morphology of the vasculature in diabetes have been characterised in both animal and human models (Fig.1). Rats are the animal model commonly used and are rendered diabetic by treatment with streptozotocin (STZ), a nitrosamine which is toxic to the pancreatic beta-cell. In other species such as the rabbits which are more resistant to STZ [11], alloxan is used to induce diabetes.

In alloxan-induced diabetic rabbits, endothelial alterations occur in the aorta as early as 2 weeks after onset of diabetes and the changes become more severe by 6 weeks [12]. These alterations are consistent with injury and include adhesion of leucocytes, platelets and fibrin-like material to the endothelial surface [12]. Using cultured aortic endothelial cells from STZ diabetic minipigs, endothelial cells derived from diabetic minipigs have been shown to have a higher rate of proliferation and a higher percentage of large multinucleated cells [13]. Furthermore, these multinucleated cells have an increased low-density lipoprotein binding and degradation compared with non-diabetic controls [13]. In STZ-induced diabetic rats, an increased rate of aortic endothelial cell death as well as an increase in endothelial permeability in the aorta was observed at 6 weeks after onset of diabetes [14].

In humans, an increase in basement membrane (BM) thickness of the microvasculature is the major feature in Type I diabetes. Using transmission electron microscopy, BM thickening has been shown in skin capillaries in patients with Type I diabetes compared with non-diabetic subjects [15]. Additionally, it has been shown that one year of intensive glycaemic control in Type I diabetes reduces BM width in skeletal muscle capillaries [16]. Furthermore, diabetic neuropathy has been shown to be associated with an increase in BM thickening [17-19], numbers of endothelial nuclei [17], endothelial cell area [17,19,20] and capillary diffusion capacity as measured by clearance of radiolabelled xenon and iodide from hyperaemic leg muscles [21]. Recently, more features of endothelial alteration in diabetes were shown by transmission electron microscopy and fluorescence anisotropy using specific fluorescent probe anchoring at the endothelial surface membrane [22]. These included an increase in fluidity of the endothelial membrane, an increase in mitochondrial area and a more fluid phase endocytosis in endothelial cells obtained from umbilical cords of Type I diabetic pregnant women compared with non-diabetic control subjects [22].

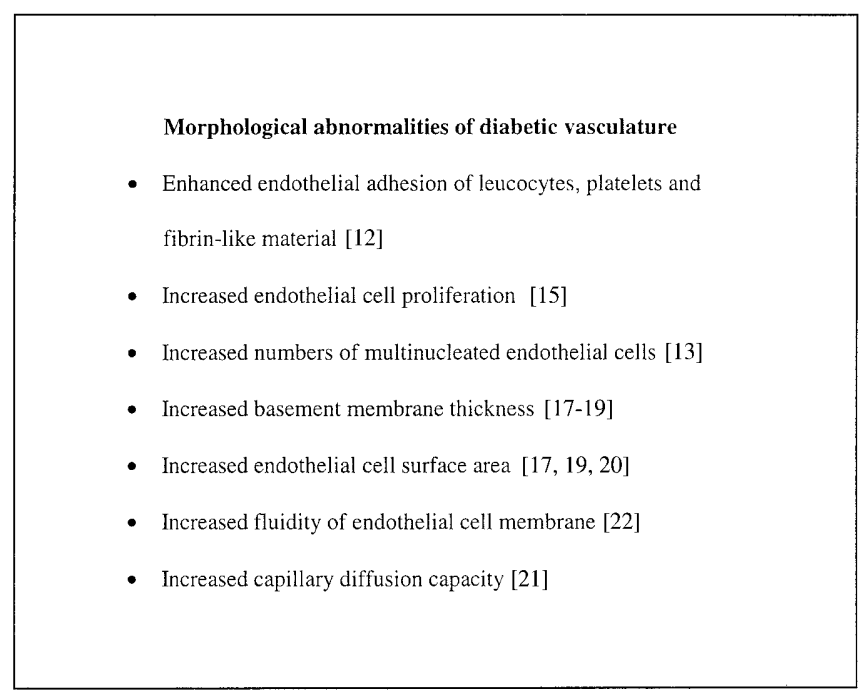

Fig.1. Morphological abnormalities of diabetic vasculature

The functional relevance of these structural abnormalities is not clear as yet but they could contribute to vasculopathy and premature atherosclerosis in Type I diabetes.

\section{L-arginine: nitric oxide: cGMP pathway}

In 1980, endothelium-dependent relaxation was shown in vascular tissues [23]. This was found to be mediated by endothelial-derived relaxing factor, which has subsequently been identified as nitric oxide (NO) $[10,24]$. Endothelial-derived NO is synthesised from the guanidine-nitrogen terminal of the amino acid L-arginine by the endothelium isoform of NO synthase (eNOS) [25,26]. Nitric oxide has a half-life of only a few seconds [27] and is rapidly oxidised to nitrate by oxygenated haemoglobin, molecular oxygen and superoxide anions, before being excreted into the urine [28]. In addition to being a very potent vasodilator, endothelium-derived $\mathrm{NO}$ also has antiatherogenic properties including decreasing platelet and leucocyte adhesion to the endothelium and inhibition of VSMC migration [6]. These effects are mediated largely through activation of guanylate cyclase, leading to increases in cyclic guanosine monophosphate (cGMP) within platelets or smooth muscle cells (Fig. 2) [29, 30].

Nitric oxide is released under physiological conditions [31] regulating basal blood flow in healthy humans [32]. This basal NO release is inhibited by $N^{\mathrm{G}}$ monomethyl-L-arginine (L-NMMA), a specific inhibitor of NOS [32]. Endothelial NO synthesis can also be stimulated by a variety of physical and biochemical stimuli. These include shear stress [33, 34], pulsatile stretching of the vessel wall $[35,36]$, low arterial oxygen tension [37], receptor-dependent agonists (e.g. acetylcholine, bradykinin) and receptor-inde- 

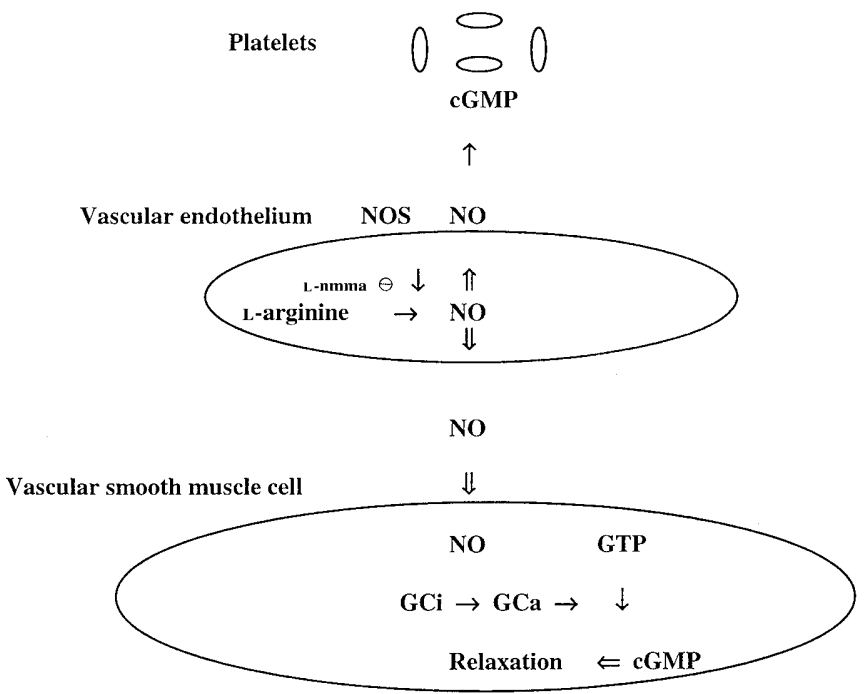

Fig. 2. The nitric oxide: L-arginine pathway. Endothelial-derived nitric oxide (NO) is synthesised from L-arginine by NO synthase (NOS). Nitric oxide diffuses across to vascular smooth muscle cell and platelets to cause vasorelaxation and inhibition of platelet aggregation, respectively. Both processes are mediated through cyclic GMP (cGMP). Synthesis of NO can be inhibited by $\mathrm{L}-N^{\mathrm{G}}$-monomethyl-arginine (L-NMMA), an NOS-inhibitor. GCi, inactive guanylate cyclase; GCa, active guanylate cyclase

pendent agonists (e.g. calcium ionophores, polycations or calcium-ATPase inhibitors) $[10,38,39]$. Determination of vasoconstriction in response to $\mathrm{L}$ NMMA or vasodilatation in response to acetylcholine in a vascular bed or an isolated blood vessel has been used to infer basal NO release and stimulated NO-mediated vasodilatation respectively, in human and animal models with diabetic vascular disease [40].

\section{Defective response to NO or reduced NO availability in Type I diabetes?}

Given the potential antiatherogenic properties of $\mathrm{NO}$, it is possible that a defect in the L-arginine: NO: cGMP pathway contributes to the increased cardiovascular risk in Type I diabetes. This defect could occur at one or several stages of the pathway. There could be reduced basal or stimulated NO release or both, decreased bioavailability of $\mathrm{NO}$ or reduced VSMC responsiveness. Experimental evidence suggests that all these defects are plausible in Type I diabetes. For example, it has been shown that the vasodilating effect of insulin in skeletal muscle is mediated through an increase in NO release [41]. Hence in the presence of insulin deficiency in Type I diabetes, there could be reduced NO release. Even if NO release is normal, its bioavailability could be reduced because advanced glycation end products, as a result of chronic hyperglycaemia, quench NO in vitro [42]. Alternatively, there could be defective VSMC re- sponse to NO as hyperglycaemia interferes with NOinduced guanylate cyclase activation [43].

\section{Endothelium-dependent vascular responses in Type I diabetes}

As discussed below [44, 45] studies assessing endothelial function in both animal and human models of Type I diabetes have produced conflicting results. In experimental models, endothelial function is modulated by a number of factors associated with Type I diabetes including degree of acute hyperglycaemia [46-49], diabetes duration (possibly associated with accumulation of advanced glycation end products) $[42,50]$, insulin concentrations [51, 52], and the presence or absence of diabetic complications such as autonomic neuropathy [53] and microalbuminuria [54]. Variation in these factors between different studies might account for the conflicting results.

\section{Animal studies}

In conduit vessel studies, endothelium-dependent relaxation in diabetic animal models has been reported to be either impaired $[55,56]$ or normal $[57-60]$ compared with controls. A similar disparity has also been observed in resistance vessels with endothelium-dependent relaxation being found to be impaired [61-64] or normal [65]. In some animal studies, endothelium-dependent relaxation has even been enhanced $[66,67]$. This disparity is possibly due to differences in disease duration, the vascular bed studied and methods of vessel preparation (e.g. using helical strips [68]) which determine the extent of vascular endothelium preservation. For example, there is a substantial difference in the timing between impairment of endothelial-dependent relaxation and onset of diabetes in different vascular beds, ranging from 1 week in intestinal arterioles [69] to between 4 and 6 weeks in mesenteric arteries [70, 71]. An additional factor to consider is the possible cross-over effects due to multiple drug application in the same specimen [57].

The importance of disease duration has been highlighted in a recent study [72]. Using aortic rings of STZ-induced diabetic rats, pre-contracted with norepinephrine, endothelium-dependent relaxation to acetylcholine was increased at $24 \mathrm{~h}$ after injection with STZ, normal after 1 and 2 weeks of disease and impaired at 8 weeks of disease compared with controls [72]. In both control and diabetic aortic rings, acetylcholine-induced relaxation was blocked using L-nitroarginine suggesting that the enhanced response was mediated through NO [72]. This is the first study to show the triphasic response in relation to disease duration in diabetic animal models. 
Table 1. Summary of in vivo endothelial function studies by venous occlusion plethysmography in human Type I diabetes mellitus

\begin{tabular}{|c|c|c|c|c|c|c|c|}
\hline Authors & $\begin{array}{l}\text { Numbers } \\
\text { (female/male) }\end{array}$ & $\begin{array}{l}\text { Mean disease } \\
\text { duration (years) }\end{array}$ & $\mathrm{HbA}_{1 \mathrm{c}}(\%)$ & $\begin{array}{l}\text { Euglycaemic- } \\
\text { insulin clamp }\end{array}$ & $\begin{array}{l}\text { Diabetic } \\
\text { complications }\end{array}$ & $\begin{array}{l}\text { Stimulated } \\
\text { NO response }\end{array}$ & $\begin{array}{l}\text { Endothelium-inde- } \\
\text { pendent response }\end{array}$ \\
\hline \multicolumn{8}{|c|}{ Venous occlusion plethysmography } \\
\hline $\begin{array}{l}\text { Calver } \\
\text { et al [82] }\end{array}$ & $10(0 / 10)$ & "Recent onset" & $6.7 \pm 0.5$ & No & without & unchanged & $\begin{array}{l}\text { unchanged } \\
\text { (verapamil) } \\
\text { impaired (SNP) }\end{array}$ \\
\hline $\begin{array}{l}\text { Johnstone } \\
\text { et al [76] }\end{array}$ & $15(11 / 4)$ & $14 \pm 2$ & $11.9 \pm 0.6$ & No & not stated & impaired & $\begin{array}{l}\text { unchanged } \\
\text { (SNP + verapamil) }\end{array}$ \\
\hline $\begin{array}{l}\text { Huvers } \\
\text { et al [80] }\end{array}$ & $34(7 / 27)$ & 17 & 8.98 & Yes & with and without & unchanged & unchanged (SNP) \\
\hline Elliott & $14(6 / 8)$ & 20.7 & $3.3^{\mathrm{a}}$ & Yes & normoalbuminuria & impaired & unchanged (SNP) \\
\hline et al [54] & $14(3 / 11)$ & 22.6 & $3.3^{\mathrm{a}}$ & Yes & microalbuminuria & unchanged & unchanged (SNP) \\
\hline $\begin{array}{l}\text { Halkin } \\
\text { et al [81] }\end{array}$ & $18(2 / 16)$ & $12.0 \pm 8.0$ & $4.074 \pm 0.207^{\mathrm{a}}$ & No & without & unchanged & unchanged (SNP) \\
\hline \multirow{2}{*}{$\begin{array}{l}\text { Makimattila } \\
\text { et al [53] }\end{array}$} & $10(0 / 10)$ & $28 \pm 3$ & $8.6 \pm 0.3$ & Yes & \multirow{2}{*}{$\begin{array}{l}\text { macroalbuminuria } \\
\& \text { autonomic dysf. } \\
\text { microalbuminuria } \\
\& \text { autonomic dysf. }\end{array}$} & enhanced & enhanced (SNP) \\
\hline & $12(0 / 12)$ & $18 \pm 3$ & $8.6 \pm 0.3$ & Yes & & unchanged & unchanged (SNP) \\
\hline
\end{tabular}

${ }^{a}$ Fructosamine $(\mathrm{mmol} / \mathrm{l})$

\section{Human studies}

\section{In vitro studies}

There have been two studies on in vitro endotheliumdependent relaxation. Using isolated resistance arteries (from biopsy specimens of subcutaneous fat from the gluteal region) from Type I diabetic patients, impaired relaxation to acetylcholine but not to bradykinin or sodium nitroprusside (SNP) has been shown in pre-contracted small arteries [73]. The normal vascular response to bradykinin in that study suggests defective endothelial cell acetylcholine receptor excitation-coupling in Type I diabetes rather than a reduction in NO synthesis [73]. Recently, resistance vessels dissected from gluteal fat biopsy specimens in normotensive Type I diabetic patients with varying degrees of microvascular complications were examined. The preliminary data showed no difference in acetylcholine-induced relaxation compared with non-diabetic specimens [74].

\section{In vivo studies}

\section{Forearm venous occlusion plethysmography}

Agonist-stimulated vascular responses. This technique has been used to study human resistance arteries [75] in Type I diabetes. Endothelium-dependent vasodilatation is assessed by intra-arterial (brachial artery) infusion of muscarinic agonists (acetylcholine, methacholine or carbachol). Using this method, endothelium-dependent relaxation in Type I diabetic patients has been shown to be impaired [76-78], normal [54, 79-81] and even enhanced [53] (Table 1).

Vasodilator response to nitric oxide donors. Endothelium-independent vasodilatation in Type I diabetic patients has been assessed extensively by intra-arterial infusion of sodium nitroprusside, an NO donor. Most studies using venous occlusion plethymography found that vascular response to SNP was not changed. In one study, vascular response to SNP was found to be inversely correlated with $\mathrm{Na}^{+} / \mathrm{Li}^{+}$counter-transport [81], a possible marker for the development of diabetic vascular complications. In another study a diminished response to SNP was, however, observed [82] which could be attributable to reduced VSMC sensitivity to NO. Verapamil was used in two studies as an NO-independent vasodilator $[76,82]$ to determine whether any impaired vasodilatation to SNP is specific for NO pathways. In both studies, vascular response to verapamil was unchanged.

Vasoconstrictor response to nitric oxide synthase inhibitor. In the assessment of basal NO release using intra-arterial infusion of L-NMMA, data are also inconsistent. The vasoconstrictor response to $\mathrm{L}-$ NMMA was unchanged in one study [80] but blunted in two other studies [54, 82]. This blunted response was found to be most pronounced in Type I diabetic patients with microalbuminuria [54]. 
Table 2. Summary of in vivo endothelial function studies by vascular ultrasound in human Type I diabetes mellitus

\begin{tabular}{|c|c|c|c|c|c|c|c|}
\hline Authors & $\begin{array}{l}\text { Numbers } \\
(\mathrm{W} / \mathrm{M})\end{array}$ & $\begin{array}{l}\text { Mean disease } \\
\text { duration (years) }\end{array}$ & $\mathrm{HbA}_{1 \mathrm{c}}(\%)$ & $\begin{array}{l}\text { Euglycaemic- } \\
\text { insulin clamp }\end{array}$ & $\begin{array}{l}\text { Diabetic } \\
\text { complications }\end{array}$ & $\begin{array}{l}\text { Reactive } \\
\text { hyperaemia }\end{array}$ & $\begin{array}{l}\text { Endothelium-inde- } \\
\text { pendent response }\end{array}$ \\
\hline \multicolumn{8}{|c|}{ Flow-mediated vasodilatation assessed by high resolution vascular ultrasound } \\
\hline Zenere et al $[85]^{\mathrm{a}}$ & $\begin{array}{r}10(5 / 5) \\
8(6 / 2)\end{array}$ & $\begin{array}{l}10 \pm 1 \\
11 \pm 1\end{array}$ & $\begin{array}{l}7.7 \pm 0.2 \\
7.2 \pm 0.5\end{array}$ & $\begin{array}{l}\text { No } \\
\text { No }\end{array}$ & $\begin{array}{l}\text { normoalbuminuria } \\
\text { microalbuminuria }\end{array}$ & $\begin{array}{l}\text { impaired } \\
\text { impaired }\end{array}$ & $\begin{array}{l}\text { impaired (GTN) } \\
\text { impaired (GTN) }\end{array}$ \\
\hline Lambert et al [84] & $52(22 / 30)$ & $14.9 \pm 8$ & $7.9 \pm 1.2$ & No & retinopathy only & unchanged & unchanged (GTN) \\
\hline Lekakis et al [87] & $\begin{array}{c}5(4 / 1) \\
26(17 / 9)\end{array}$ & $\begin{array}{r}20 \pm 8.5 \\
12.9 \pm 8.4\end{array}$ & $\begin{array}{l}7.1 \pm 1.0 \\
6.5 \pm 1.5\end{array}$ & $\begin{array}{l}\text { No } \\
\text { No }\end{array}$ & $\begin{array}{l}\text { microalbuminuria } \\
\text { normoalbuminuria }\end{array}$ & $\begin{array}{l}\text { impaired } \\
\text { impaired }\end{array}$ & $\begin{array}{l}\text { impaired (ISDN) } \\
\text { unchanged (ISDN) }\end{array}$ \\
\hline Mecking et al [93] & $\begin{array}{l}18(10 / 8) \\
18(10 / 8)\end{array}$ & $\begin{array}{l}27.8 \pm 2.4 \\
26.9 \pm 2.0\end{array}$ & $\begin{array}{c}10.5 \pm 2 \\
9.6 \pm 0.3\end{array}$ & $\begin{array}{l}\text { No } \\
\text { No }\end{array}$ & $\begin{array}{l}\text { microalbuminuria } \\
\text { normoalbuminuria }\end{array}$ & $\begin{array}{l}\text { impaired } \\
\text { impaired }\end{array}$ & $\begin{array}{l}\text { unchanged (GTN) } \\
\text { unchanged (GTN) }\end{array}$ \\
\hline
\end{tabular}

a The common femoral artery was studied by echo-ultrasound, $\mathrm{W} / \mathrm{M}=$ women $/ \mathrm{men}$

\section{Flow-mediated dilatation assessed by vascular ultrasound}

Endothelial function of conduit vessels (mainly the brachial artery) has been evaluated using high resolution vascular Doppler ultrasound [83] to determine the degree of flow-mediated dilatation (FMD) [84-87]. The brachial artery is used because it is easily accessable and there is some evidence that endothelial dysfunction in brachial artery parallels that of the coronary artery [88]. Although this method of evaluating endothelial function is non-invasive, it has the disadvantage that a highly skilled ultrasonographer is required for imaging to be done accurately and reproducibly. This technique has a relatively low within person reproducibility [89]. Furthermore, differences in the flow velocity profile during reactive hyperaemia could lead to poor reproducibility of flow-mediated dilatation [90]. The brachial arteries have mostly been used although one study assessed the common femoral artery [85]. The results are again conflicting with endothelium-dependent vascular responses shown to be impaired $[85,87,91]$ or unchanged [84, 86] (Table 2).

Similarly, endothelium-independent vascular response to glyceryl trinitrate was found to be either impaired $[85,90]$ or unchanged $[86,91]$. In studies showing reduction in FMD in Type I diabetic patients, there does not seem to be a relation with presence or absence of microalbuminuria [90, 92].

\section{Conflicting data in human in vivo studies: potential factors}

Sex difference. The sex difference in CHD incidence is abolished in Type I diabetes [4]. If there is any differential effect of diabetes on endothelial function between the sexes, then differences between studies could arise if the proportion of women in the studies differs. Furthermore, forearm length (and hence ves- sel length) is different between men and women. This could result in differences in vascular responses to acetylcholine [93] because acetylcholine is rapidly destroyed by cholinesterase enzymes and the magnitude of response is partially dependent on forearm length [94]. With the exception of one study [76], venous occlusion plethysmography studies have been done predominantly in male diabetic subjects [54, 80] with female diabetic subjects not being included at all in some studies [53, 78, 79, 82]. There is some suggestion from table 1 that many of the negative studies are those which have included relatively few women. Hence, it is possible that the different male to female ratio between studies contributed to the conflicting results.

Effect of glycaemic control. There is a large variation in mean $\mathrm{HbA}_{1 \mathrm{c}}$, or glycated haemoglobin, in Type I diabetic patients included in different studies. The greatest contrast is between $\mathrm{HbA}_{1 \mathrm{c}} 6.7 \%$ [82] and $\mathrm{HbA}_{1 \mathrm{c}} 11.9 \%$ [76]. In the first study stimulated endothelium-dependent vasodilatation was not changed and in the second it was impaired. Most research groups have studied patients with suboptimal glycaemic control with $\mathrm{HbA}_{1 \mathrm{c}}$ ranging from 8.3-9.2\% [53, 78-80].

Degree of acute hyperglycaemia. There is substantial evidence that acute hyperglycaemia attenuates endothelium-dependent vasodilatation [47, 48]. It is possible that the variable degree of hyperglycaemia at the time of measurement in different studies had an effect on endothelium-dependent vascular responses. To minimise the acute hyperglycaemic effect during studies, some groups have used the euglycaemic-insulin clamp method to maintain normoglycaemia $[78,80]$.

Different muscarinic agonists. Methacholine, acetylcholine and carbachol have all been used to stimulate NO production. Direct comparisons between studies 
using different muscarinic agonists should be made with caution. It has been shown in some studies that vasodilatation response to acetylcholine is attenuated by L-NMMA whereas that to methacholine is not [95].

Effects of diabetic complications. Several groups have used Type I diabetic patients without microvascular complications in whom endothelium-dependent responses were found either not to be changed $[79,82]$ or to be impaired $[54,78]$. In the only human in vivo study with Type I diabetic patients where autonomic dysfunction was documented, hyperresponsiveness to acetylcholine (as well as to SNP, an endotheliumindependent vasodilator) was found in those with macroalbuminuria [53]. It has been suggested that this hyperresponsiveness to acetylcholine is a result of increased sensitivity of the VSMC as it would also explain the hyperresponsiveness to SNP [96].

An important limitation in all these in vivo human studies using forearm venous occlusion plethysmography is that although patients with clinical macrovascular complications are excluded, it is possible that some patients have subclinical macrovascular complications (asymoptomatic atherosclerosis) which has a relevant effect on endothelial function. It has been shown in a recent study using electron beam computed tomography that there is a high prevalance of coronary artery calcification (a validated measure of atheroma burden) in young (age 30-55) patients with Type I diabetes [97]. Furthermore, the studies have all been quite small and do not allow evaluation of the effects of concomitant diabetic complications. To establish the important determinants of endothelial function in Type I diabetes, a large study is needed in which the effect of factors such as sex, disease duration, diabetic complications and glycaemic control can be evaluated.

\section{Potential mechanisms for endothelial dysfunction in Type I diabetes}

The mechanisms whereby Type I diabetes is associated with endothelial dysfunction are complex and not completely understood. Although the concomitant presence of hypertension and dyslipidaemia in Type I diabetes could contribute directly to endothelial dysfunction, a combination of several mechanisms directly related to increased glucose concentration could also be responsible and are the focus of the remainder of this paper.

\section{Role of free radicals}

There is substantial evidence to indicate that hyperglycaemia-induced endothelial dysfunction is mediat- ed by free radicals produced through increased arachidonic acid metabolism [98-100]. It has been shown that in human aortic endothelial cells, prolonged exposure to high concentrations of glucose increases $e N O S$ gene expression and NO release. This is associated, however, with a pronounced concomitant increase of superoxide anion production [101]. These anions inactivate NO and furthermore, they interact with $\mathrm{NO}$ leading to production of peroxynitrite $[102,103]$, a potent oxidant, which in turn stimulates cyclooxygenase catalysis, lipid peroxidation and increased prostanoid production resulting in endothelial dysfunction [104, 105]. Superoxide dismutase, a scavenger of superoxide anion, has been shown to normalise NO-mediated vasorelaxation impaired by increased glucose concentrations [98, 106, 107]. Recently, NO synthesis and oxidative stress have been quantified by measuring radiolabelled nitrite and 8epiPGF $2 \alpha$ [108]. The preliminary results showed an inverse relation between NO synthesis and free radical activity [108]. Thus hyperglycaemia could induce increased NO production as well as reduced NO availability due to inactivation mediated by free radicals.

\section{Aldose reductase and the polyol pathway}

Chronic hyperglycaemia increases aldose reductase activity leading to an increase in glucose metabolism through the polyol pathway $[109,110]$ in which it is first metabolised to sorbitol and subsequently to fructose (Fig. 3). Aldose reductase has been shown to be present in the vascular endothelial cells [111] and is the rate-limiting enzyme in the initial conversion of glucose to sorbitol. This process is dependent on nicotinamide-adenine dinucleotide phosphate (NADPH) and therefore results in an increase in its use [109, 112]. Because NADPH is also an essential cofactor for NOS for the synthesis of NO, its depletion as a result of chronic hyperglycaemia could lead to a reduction in NO production. Aldose reductase inhibitors have shown early promise in reversing glucose-induced changes in sorbitol and myo-inositol metabolism and endothelial dysfunction in experimental diabetes [113-115]. It remains to be determined, however, whether aldose reductase inhibitors have a part in the prevention of atherosclerosis in humans.

\section{Protein kinase C}

Activation of protein kinase $\mathrm{C}$ (PKC) by increases in diacylglycerol (DAG) induced by hyperglycaemia has been suggested as a mechanism for endothelial dysfunction and vascular complication in diabetes $[116,117]$. Such activation has been shown to be associated with increased urinary albumin excretion in rats [117]. Indeed, PKC activation is responsible for 
Glucose

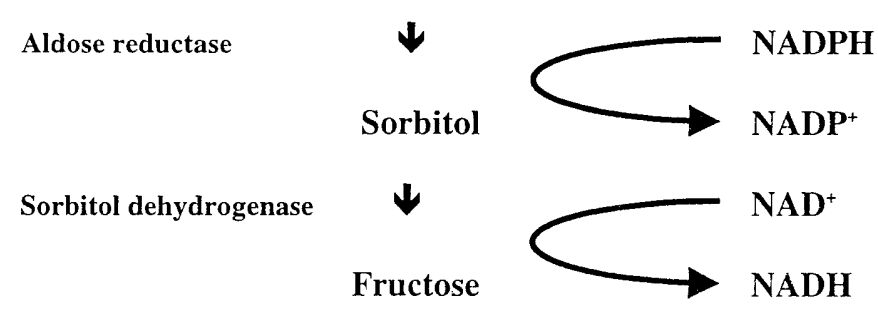

Fig. 3. The polyol pathway: glucose is converted by aldose reductase to sorbitol which is metabolised to fructose by sorbitol dehydrogenase. This process is dependent on nicotinamide-adenine dinucleotide phosphate (NADPH) and oxidised nicotinamide-adenine dinucleotide $\left(\mathrm{NAD}^{+}\right)$

several vascular alterations in diabetes such as a decrease in the activity of $\mathrm{Na}^{+}-\mathrm{K}^{+}$-adenosine triphosphatase, increases in extracellular matrix, cytokines, permeability, contractility and cell proliferation [116] and an increase in vasoconstrictor prostanoids [118]. Isolated rabbit aorta exposed to increased glucose concentrations had impaired endothelium-dependent relaxation to acetylcholine after $10 \mathrm{~min}$ treatment with 4-phorbol 12-myristate 13-acetate, a PKC activator [118]. Indomethacin increased relaxation induced by acetylcholine, suggesting a role for vasoconstrictor prostanoids, and this abnormal relaxation was restored with sphingosine, a PKC inhibitor [118].

\section{Advanced glycation end products}

In the presence of sustained high plasma glucose concentrations, circulating or tissue-structure proteins including arterial wall collagen and glomerular basement-membrane proteins undergo covalent, non-enzymatic glycation and cross-linking resulting in the formation of advanced glycation end products (AGEs) $[119,120]$. Advanced glycation end products possibly contribute to endothelial dysfunction and diabetic vascular complication by permanent chemical modification of circulating cells and proteins, and indirectly by stimulating cellular response through receptors specific for AGE-modified proteins [121, 122]. These specific receptors for AGE-modified proteins have been identified in murine and human macrophage cells which are thought to have a key role in the clearance of AGE-modified proteins [121, 122]. Rate of accumulation of AGEs seems to be faster than normal in arteries and circulation of patients with diabetic nephropathy consistent with the renal tract being the main, if not only, source of clearance [123]. Accumulation of AGEs over time has been shown to reduce NO availability. Studies using a rat model of STZ-induced diabetes showed both in vitro and in vivo that early in the advanced glycation pathway, reactive intermediates form which then react with and quench NO rapidly ( $<5 \mathrm{~s}$ ) as a result of direct reaction between $\mathrm{NO}$ radical and the AGEs [124]. In addition to NO inactivation, AGEs have been shown to impair the effects of NO on mesangial cells antiproliferation, an early and characteristic lesion of diabetic vasculopathy [125].

Aminoguanidine, an inhibitor of AGEs formation [126], has been shown in diabetic rats to partially restore endothelium-dependent relaxation in vivo [124] and to reduce albuminuria associated with hypertension [126] and to retard the development of diabetic nephropathy [127]. It should, however, be noted that aminoguanidine has multiple actions including direct effects on $\mathrm{NO}$ generation.

\section{Conclusions}

Studies in experimental animals and in vitro have shown that loss of NO is associated with increased vascular reactivity to constrictors, enhanced platelet adhesion and aggregation, increased adhesion of leucocytes, promotion of VSMC growth and accelerated atherogenesis [40]. Type I diabetes could affect NO production through generalised actions on the endothelium or through specific effects on the NO pathway. For example, there could be specific defects in signal transduction mechanisms linked to NO synthase (receptors, ion channels), NO synthase expression, post-translational modification of the enzyme or destruction of the NO once it has been made. In addition, it is possible that down-regulation of guanylate cyclase or the other effector mechanisms of NO could be affected. Although many studies in animal models have indicated that Type I diabetes is indeed associated with functional defects in parts of the NO pathway, in humans the data are conflicting and there is no clear consensus about the level at which the disease might alter NO signalling. The variable results of endothelial function obtained in different studies may be partially explained by differences in methodology, blood vessel size and the presence of diabetic complications. The mechanisms underlying endothelial dysfunction could involve several biochemical pathways with an increase in glucose concentration providing the initial metabolic insult. One area which has not been studied in depth is the effect of abnormal neural control on endothelial function. Future arterial forearm studies with occlusion venous plethysmography should include sufficient numbers of patients to assess the role of autonomic dysfunction on vascular reactivity.

At present, several compounds have received attention in the prevention of diabetic vascular dysfunction and complications, including antioxidants such as vitamin $\mathrm{C}$, aldose reductase inhibitors, PKC inhibitors, aminoguanidine, L-arginine all of which have shown early promise in animal studies. The effi- 
cacy of these agents in endothelial function in humans has, however, yet to be shown. Beyond that it is then important to establish whether improvement in endothelial function can be translated into a reduction in mortality and morbidity.

Acknowledgements. This work is supported by the British Heart Foundation. We thank Dr. R. MacAllister for his helpful comments.

\section{References}

1. Head J, Fuller JH (1990) International variations in mortality among diabetic patients: the WHO Multinational Study of Vascular Disease in Diabetics. Diabetologia 33: 477-481

2. Fuller JH, Elford J, Goldblatt P, Adelstein AM (1983) Diabetes mortality: new light on an underestimated public health problem. Diabetologia 24: 336-341

3. Dorman JS, Laporte RE, Kuller LH et al. (1984) The Pittsburgh insulin-dependent diabetes mellitus (IDDM) morbidity and mortality study. Mortality results. Diabetes 33: 271-276

4. Krolewski AS, Kosinski EJ, Warram JH et al. (1987) Magnitude and determinants of coronary artery disease in juvenile-onset, insulin-dependent diabetes mellitus. Am J Cardiol 59: 750-755

5. Morrish NJ, Stevens LK, Fuller JH, Jarrett RJ, Keen H (1991) Risk factors for macrovascular disease in diabetes mellitus: the London follow-up to the WHO Multinational Study of Vascular Disease in Diabetics. Diabetologia 34: 590-594

6. Moncada S, Palmer RM, Higgs EA (1991) Nitric oxide: physiology, pathophysiology, and pharmacology. Pharmacol Rev 43: 109-142

7. Garg UC, Hassid A (1989) Nitric oxide-generating vasodilators and 8-bromo-cyclic guanosine monophosphate inhibit mitogenesis and proliferation of cultured rat vascular smooth muscle cells. J Clin Invest 83: 1774-1777

8. Porta M, La Selva M, Molinatti P, Molinatti GM (1987) Endothelial cell function in diabetic microangiopathy. Diabetologia 30: 601-609

9. Jensen T, Bjerre Knudsen J, Feldt Rasmussen B, Deckert T (1989) Features of endothelial dysfunction in early diabetic nephropathy. Lancet i: 461-463

10. Palmer RM, Ferrige AG, Moncada S (1987) Nitric oxide release accounts for the biological activity of endothelium-derived relaxing factor. Nature 327: 524-526

11. Kushner B, Lazar M, Furman M, Lieberman TW, Leopold IH (1969) Resistance of rabbits and guinea pigs to the diabetogenic effect of streptozotocin. Diabetes 18: 542-544

12. Hadcock S, Richardson M, Winocour PD, Hatton MW (1991) Intimal alterations in rabbit aortas during the first 6 months of alloxan-induced diabetes. Arterioscler Thromb 11: 517-529

13. Grunwald J, Hesz A, Robenek H, Brucker J, Buddecke E (1985) Proliferation, morphology, and low-density lipoprotein metabolism of arterial endothelial cells cultured from normal and diabetic minipigs. Exp Mol Pathol 42: $60-70$

14. Lin SJ, Hong CY, Chang MS, Chiang BN, Chien S (1993) Increased aortic endothelial death and enhanced transendothelial macromolecular transport in streptozotocin-diabetic rats. Diabetologia 36: 926-930
15. Aageneas O, Moe H (1961) Light and electron microscopy study of skin capillaries of diabetics. Diabetes 10: 253-259

16. Rosenstock J, Challis P, Strowig S, Raskin P (1988) Improved diabetes control reduces skeletal muscle capillary basement membrane width in insulin-dependent diabetes mellitus. Diabetes Res Clin Pract 4: 167-175

17. Malik RA, Tesfaye S, Thompson SD, Veves A, Sharma AK, Boulton AJ, Ward JD (1993) Endoneurial localisation of microvascular damage in human diabetic neuropathy. Diabetologia 36: 454-459

18. Matikainen E, Leinonen H, Juntunen J (1982) Capillary morphology and muscle blood flow in diabetic neuropathy. Eur Neurol 21: 22-28

19. Yasuda H, Dyck PJ (1987) Abnormalities of endoneurial microvessels and sural nerve pathology in diabetic neuropathy. Neurology 37: 20-28

20. Malik RA, Newrick PG, Sharma AK et al. (1989) Microangiopathy in human diabetic neuropathy: relationship between capillary abnormalities and the severity of neuropathy. Diabetologia 32: 92-102

21. Leinonen H, Matikainen E, Juntunen J (1982) Permeability and morphology of skeletal muscle capillaries in Type I (insulin-dependent) diabetes mellitus. Diabetologia 22: 158-162

22. Cester N, Rabini RA, Salvolini E et al. (1996) Activation of endothelial cells during insulin-dependent diabetes mellitus: a biochemical and morphological study. Eur J Clin Invest 26: 569-573

23. Furchgott RF, Zawadzki JV (1980) The obligatory role of endothelial cells in the relaxation of arterial smooth muscle by acetylcholine. Nature 288: 373-376

24. Ignarro LJ, Buga GM, Wood KS, Byrns RE, Chaudhuri G (1987) Endothelium-derived relaxing factor produced and released from artery and vein is nitric oxide. Proc Natl Acad Sci USA 84: 9265-9269

25. Schmidt HH, Nau H, Wittfoht W et al. (1988) Arginine is a physiological precursor of endothelium-derived nitric oxide. Eur J Pharmacol 154: 213-216

26. Palmer RM, Ashton DS, Moncada S (1988) Vascular endothelial cells synthesize nitric oxide from L-arginine. $\mathrm{Na}$ ture 333: 664-666

27. Moncada S, Higgs A (1993) The L-arginine-nitric oxide pathway. N Engl J Med 329: 2002-2012

28. Wennmalm A, Benthin G, Edlund A et al. (1993) Metabolism and excretion of nitric oxide in humans. An experimental and clinical study. Circ Res 73: 1121-1127

29. Furchgott RF (1984) The role of endothelium in the responses of vascular smooth muscle to drugs. Annu Rev Pharmacol Toxicol 24: 175-197

30. Griffith TM, Edwards DH, Lewis MJ, Newby AC, Henderson AH (1984) The nature of endothelium-derived vascular relaxant factor. Nature 308: 645-647

31. Ignarro LJ (1989) Biological actions and properties of endothelium-derived nitric oxide formed and released from artery and vein. Circ Res 65: 1-21

32. Vallance P, Collier J, Moncada S (1989) Effects of endothelium-derived nitric oxide on peripheral arteriolar tone in man. Lancet ii: 997-1000

33. Pohl U, Holtz J, Busse R, Bassenge E (1986) Crucial role of endothelium in the vasodilator response to increased flow in vivo. Hypertension 8: 37-44

34. Tada M, Kirchberger MA, Katz AM (1975) Phosphorylation of a 22,000-dalton component of the cardiac sarcoplasmic reticulum by adenosine $3^{\prime}: 5^{\prime}$-monophosphate-dependent protein kinase. J Biol Chem 250: 2640-2647 
35. Hutcheson IR, Griffith TM (1991) Release of endothelium-derived relaxing factor is modulated both by frequency and amplitude of pulsatile flow. Am J Physiol 261: $\mathrm{H} 257-\mathrm{H} 262$

36. Lamontagne D, Pohl U, Busse R (1992) Mechanical deformation of vessel wall and shear stress determine the basal release of endothelium-derived relaxing factor in the intact rabbit coronary vascular bed. Circ Res 70: 123-130

37. Pohl U, Busse R (1989) Hypoxia stimulates release of endothelium-derived relaxant factor. Am J Physiol 256: H1595-H1600

38. Newby AC, Henderson AH (1990) Stimulus-secretion coupling in vascular endothelial cells. Annu Rev Physiol 52: 661-674

39. Hecker M, Siegle I, Macarthur H, Sessa WC, Vane JR (1992) Role of intracellular thiols in release of EDRF from cultured endothelial cells. Am J Physiol 262: H888-H896

40. Busse R, Mulsch A, Fleming I, Hecker M (1993) Mechanism of nitric oxide release from the vascular endothelium. Circulation 87:V18-V25

41. Steinberg HO, Brechtel G, Johnson A, Fineberg N, Baron AD (1994) Insulin-mediated skeletal muscle vasodilation is nitric oxide dependent. A novel action of insulin to increase nitric oxide release. J Clin Invest 94: 1172-1179

42. Bucala R, Tracey KJ, Cerami A (1991) Advanced glycosylation products quench nitric oxide and mediate defective endothelium-dependent vasodilatation in experimental diabetes. J Clin Invest 87: 432-438

43. Weisbrod RM, Brown ML, Cohen RA (1993) Effect of elevated glucose on cyclic GMP and eicosanoids produced by porcine aortic endothelium. Arterioscler Thromb 13: 915-923

44. Poston L, Taylor PD (1995) Glaxo/MRS Young Investigator Prize. Endothelium-mediated vascular function in insulin-dependent diabetes mellitus. Clin Sci (Colch) 88: 245-255

45. Pieper GM (1998) Review of alterations in endothelial nitric oxide production in diabetes: protective role of arginine on endothelial dysfunction. Hypertension 31: 1047-1060

46. Schaffler A, Arndt H, Scholmerich J, Palitzsch K (1998) Acute hyperglycaemia causes severe disturbances of mesenteric microcirculation in an in vivo rat model. Eur J Clin Invest 28: 886-893

47. Akbari CM, Saouaf R, Barnhill DF, Newman PA, LoGerfo FW, Veves A (1998) Endothelium-dependent vasodilatation is impaired in both microcirculation and macrocirculation during acute hyperglycemia. J Vasc Surg 28: 687-694

48. Williams SB, Goldfine AB, Timimi FK et al. (1998) Acute hyperglycemia attenuates endothelium-dependent vasodilation in humans in vivo. Circulation 97: 1695-1701

49. Kawano H, Motoyama T, Hirashima O et al. (1999) Hyperglycemia rapidly suppresses flow-mediated endothelium-dependent vasodilation of brachial artery. J Am Coll Cardiol 34: 146-154

50. Hogan M, Cerami A, Bucala R (1992) Advanced glycosylation endproducts block the antiproliferative effect of nitric oxide. Role in the vascular and renal complications of diabetes mellitus. J Clin Invest 90: 1110-1115

51. Scherrer U, Randin D, Vollenweider P, Vollenweider L, Nicod P (1994) Nitric oxide release accounts for insulin's vascular effects in humans. J Clin Invest 94: 2511-2515

52. Steinberg HO, Brechtel G, Johnson A, Fineberg N, Baron AD (1994) Insulin-mediated skeletal muscle vasodilation is nitric oxide dependent. A novel action of insu- lin to increase nitric oxide release. J Clin Invest 94: $1172-1179$

53. Makimattila S, Mantysaari M, Groop PH et al. (1997) Hyperreactivity to nitrovasodilators in forearm vasculature is related to autonomic dysfunction in insulin-dependent diabetes mellitus. Circulation 95: 618-625

54. Elliott TG, Cockcroft JR, Groop PH, Viberti GC, Ritter JM (1993) Inhibition of nitric oxide synthesis in forearm vasculature of insulin-dependent diabetic patients: blunted vasoconstriction in patients with microalbuminuria. Clin Sci Colch 85: 687-693

55. Oyama Y, Kawasaki H, Hattori Y, Kanno M (1986) Attenuation of endothelium-dependent relaxation in aorta from diabetic rats. Eur J Pharmacol 132: 75-78

56. Miyata N, Tsuchida K, Okuyama S, Otomo S, Kamata K, Kasuya Y (1992) Age-related changes in endothelium-dependent relaxation in aorta from genetically diabetic WBN/Kob rats. Am J Physiol 262: H1104-H1109

57. Head RJ, Longhurst PA, Panek RL, Stitzel RE (1987) A contrasting effect of the diabetic state upon the contractile responses of aortic preparations from the rat and rabbit. Br J Pharmacol 91: 275-286

58. Harris KH, MacLeod KM (1988) Influence of the endothelium on contractile responses of arteries from diabetic rats. Eur J Pharmacol 153: 55-64

59. Mulhern M, Docherty JR (1989) Effects of experimental diabetes on the responsiveness of rat aorta. Br J Pharmacol 97: 1007-1012

60. Brands MW, Fitzgerald SM (1998) Acute endotheliummediated vasodilation is not impaired at the onset of diabetes. Hypertension 32: 541-547

61. Taylor PD, Wickenden AD, Mirrlees DJ, Poston L (1994) Endothelial function in the isolated perfused mesentery and aortae of rats with streptozotocin-induced diabetes: effect of treatment with the aldose reductase inhibitor, ponalrestat. Br J Pharmacol 111: 42-48

62. Alsip NL, Schuschke DA, Miller FN (1996) Microvascular responses in the skeletal muscle of the diabetic rat. $\mathbf{J}$ Lab Clin Med 128: 429-437

63. Keegan A, Cotter MA, Cameron NE (1999) Effects of diabetes and treatment with the antioxidant alpha-lipoic acid on endothelial and neurogenic responses of corpus cavernosum in rats. Diabetologia 42: 343-350

64. Kihara M, Low PA (1995) Impaired vasoreactivity to nitric oxide in experimental diabetic neuropathy. Exp Neurol 132: 180-185

65. Gebremedhin D, Koltai MZ, Pogatsa G, Magyar K, Hadhazy P (1999) Influence of experimental diabetes on the mechanical responses of canine coronary arteries: role of endothelium. Cardiovasc Res 22: 537-544

66. Heygate KM, Lawrence IG, Bennett MA, Thurston H (1995) Impaired endothelium-dependent relaxation in isolated resistance arteries of spontaneously diabetic rats. Br J Pharmacol 116: 3251-3259

67. Altan VM, Karasu C, Ozuari A (1989) The effects of type1 and type-2 diabetes on endothelium-dependent relaxation in rat aorta. Pharmacol Biochem Behav 33: 519-522

68. Wakabayashi I, Hatake K, Kimura N, Kakishita E, Nagai K (1999) Modulation of vascular tone by the endothelium in experimental diabetes. Life Sci 40: 643-648

69. Lash JM, Bohlen HG (1991) Structural and functional origins of supressed acetylcholine vasodilation in diabetic rat intestinal arterioles. Circ Res 69: 1259-1268

70. Diederich D, Skopec J, Diederich A, Dai FX (1994) Endothelial dysfunction in mesenteric resistance arteries of diabetic rats: role of free radicals. Am J Physiol 266: H1153-H1161 
71. Kiff RJ, Gardiner SM, Compton AM, Bennett T (1991) Selective impairment of hindquarters vasodilator responses to bradykinin in conscious Wistar rats with streptozotocin-induced diabetes mellitus. $\mathrm{Br} \mathrm{J}$ Pharmacol 103: 1357-1362

72. Pieper GM (1999) Enhanced, unaltered and impaired nitric oxide-mediated endothelium-dependent relaxation in experimental diabetes mellitus: importance of disease duration. Diabetologia 42: 204-213

73. McNally PG, Watt PA, Rimmer T, Burden AC, Hearnshaw JR, Thurston H (1994) Impaired contraction and endothelium-dependent relaxation in isolated resistance vessels from patients with insulin-dependent diabetes mellitus. Clin Sci (Colch) 87: 31-36

74. Malik RA, Paniagua O, Shaw L, Austin C, Heagerty AM (1999) Resistance vessel function and structure in normotensive patients with Type I diabetes. Diabetologia 42[Suppl 1]:A75 (Abstract)

75. Benjamin N, Calver A, Collier J, Robinson B, Vallance P, Webb D (1995) Measuring forearm blood flow and interpreting the responses to drugs and mediators. Hypertension 25: 918-923

76. Johnstone MT, Creager SJ, Scales KM, Cusco JA, Lee BK, Creager MA (1993) Impaired endothelium-dependent vasodilation in patients with insulin-dependent diabetes mellitus. Circulation 88: 2510-2516

77. Makimattila S, Virkamaki A, Groop PH et al. (1996) Chronic hyperglycemia impairs endothelial function and insulin sensitivity via different mechanisms in insulin-dependent diabetes mellitus. Circulation 94: 1276-1282

78. O'Driscoll G, Green D, Rankin J, Stanton K, Taylor R (1997) Improvement in endothelial function by angiotensin converting enzyme inhibition in insulin-dependent diabetes mellitus. J Clin Invest 100: 678-684

79. Smits P, Kapma JA, Jacobs MC, Lutterman J, Thien T (1993) Endothelium-dependent vascular relaxation in patients with type I diabetes. Diabetes 42: 148-153

80. Huvers FC, De Leeuw PW, Houben AJ et al. (1999) Endothelium-dependent vasodilatation, plasma markers of endothelial function, and adrenergic vasoconstrictor responses in type 1 diabetes under near-normoglycemic conditions. Diabetes 48: 1300-1307

81. Halkin A, Benjamin N, Doktor HS, Todd SD, Viberti G, Ritter JM (1991) Vascular responsiveness and cation exchange in insulin-dependent diabetes. Clin Sci (Colch) 81: 223-232

82. Calver A, Collier J, Vallance P (1992) Inhibition and stimulation of nitric oxide synthesis in the human forearm arterial bed of patients with insulin-dependent diabetes. J Clin Invest 90: 2548-2554

83. Celermajer DS (1998) Testing endothelial function using ultrasound. J Cardiovasc Pharmacol 32[Suppl 3]: S29-S32

84. Lambert J, Aarsen M, Donker AJ, Stehouwer CD (1996) Endothelium-dependent and -independent vasodilation of large arteries in normoalbuminuric insulin-dependent diabetes mellitus. Arterioscler Thromb Vasc Biol 16: 705-711

85. Zenere BM, Arcaro G, Saggiani F, Rossi L, Muggeo M, Lechi A (1995) Noninvasive detection of functional alterations of the arterial wall in IDDM patients with and without microalbuminuria. Diabetes Care 18: 975-982

86. Enderle MD, Benda N, Schmuelling RM, Haering HU, Pfohl M (1998) Preserved endothelial function in IDDM patients, but not in NIDDM patients, compared with healthy subjects. Diabetes Care 21: 271-277

87. Lekakis J, Papamichael C, Anastasiou H et al. (1997) Endothelial dysfunction of conduit arteries in insulin-depen- dent diabetes mellitus without microalbuminuria. Cardiovasc Res 34: 164-168

88. Anderson TJ, Uehata A, Gerhard MD et al. (1995) Close relation of endothelial function in the human coronary and peripheral circulations. J Am Coll Cardiol 26: 1235-1241

89. Hardie KL, Kinlay S, Hardy DB, Wlodarczyk J, Silberberg JS, Fletcher PJ (1997) Reproducibility of brachial ultrasonography and flow-mediated dilatation (FMD) for assessing endothelial function. Aust N Z J Med 27: 649-652

90. Celermajer DS, Sorensen KE, Gooch VM et al. (1992) Non-invasive detection of endothelial dysfunction in children and adults at risk of atherosclerosis. Lancet 340: 1111-1115

91. Clarkson P, Celermajer DS, Donald AE et al. (1996) Impaired vascular reactivity in insulin-dependent diabetes mellitus is related to disease duration and low density lipoprotein cholesterol levels. J Am Coll Cardiol 28: 573-579

92. Meeking DR, Cummings MH, Thorne S et al. (1999) Endothelial dsyfunction in type 1 diabetic subjects with and without microalbuminuria. Diabet Med 16: 841-847

93. Chowienczyk PJ, Cockcroft JR, Ritter JM (1994) Blood flow responses to intra-arterial acetylcholine in man: effects of basal flow and conduit vessel length. Clin Sci (Colch) 87: 45-51

94. Duff F, Greenfield ADM, Shepherd JT, Thompson ID (1953) A quantitative study of the response to acetylcholine and histamine of the blood vessels of the human hand and forearm. J Physiol (Lond) 120: 160-170

95. Chowienczyk PJ, Cockcroft JR, Ritter JM (1993) Differential inhibition by NG-monomethyl-L-arginine of vasodilator effects of acetylcholine and methacholine in human forearm vasculature. Br J Pharmacol 110: 736-738

96. Steinberg HO, Baron AD (1997) Insulin-dependent diabetes mellitus and nitrovasodilation. Important and complex interactions. Circulation 95: 560-561

97. Colhoun HM, Chaturvedi N, Fuller JH (1999) Increased coronary artery calcification in young women with type 1 diabetes compared with the general population. Diabet Med 16: A66 (Abstract)

98. Tesfamariam B, Cohen RA (1992) Free radicals mediate endothelial cell dysfunction caused by elevated glucose. Am J Physiol 263: H321-H326

99. Tesfamariam B (1994) Free radicals in diabetic endothelial cell dysfunction. Free Radic Biol Med 16: 383-391

100. Giugliano D, Ceriello A, Paolisso G (1996) Oxidative stress and diabetic vascular complications. Diabetes Care 19: 257-267

101. Cosentino F, Hishikawa K, Katusic ZS, Luscher TF (1997) High glucose increases nitric oxide synthase expression and superoxide anion generation in human aortic endothelial cells. Circulation 96: 25-28

102. Beckman JS, Beckman TW, Chen J, Marshall PA, Freeman BA (1990) Apparent hydroxyl radical production by peroxynitrite: implications for endothelial injury from nitric oxide and superoxide. Proc Natl Acad Sci USA 87: 1620-1624

103. Squadrito GL, Pryor WA (1995) The formation of peroxynitrite in vivo from nitric oxide and superoxide. Chem Biol Interact 96: 203-206

104. Tate RM, Morris HG, Schroeder WR, Repine JE (1984) Oxygen metabolites stimulate thromboxane production and vasoconstriction in isolated saline-perfused rabbit lungs. J Clin Invest 74: 608-613

105. Jackson RM, Chandler DB, Fulmer JD (1986) Production of arachidonic acid metabolites by endothelial cells in hyperoxia. J Appl Physiol 61: 584-591 
106. Hattori Y, Kawasaki H, Abe K, Kanno M (1991) Superoxide dismutase recovers altered endothelium-dependent relaxation in diabetic rat aorta. Am J Physiol 261: H1086-H1094

107. Diederich D, Skopec J, Diederich A, Dai FX (1994) Endothelial dysfunction in mesenteric resistance arteries of diabetic rats: role of free radicals. Am J Physiol 266: H1153-H1161

108. O'Byrne S, Forte P, Johnston A et. al. (1999) Basal nitric oxide turnover and oxidative stress levels in insulin-dependent diabetes mellitus. Diabet Med 16: A18 (Abstract)

109. Hawthorne GC, Bartlett K, Hetherington CS, Alberti KG (1989) The effect of high glucose on polyol pathway activity and myoinositol metabolism in cultured human endothelial cells. Diabetologia 32: 163-166

110. Gonzalez RG, Barnett P, Aguayo J, Cheng HM, Chylack LT Jr (1984) Direct measurement of polyol pathway activity in the ocular lens. Diabetes 33: 196-199

111. Kern TS, Engerman RL (1982) Immunohistochemical distribution of aldose reductase. Histochem J 14: 507-515

112. Asahina T, Kashiwagi A, Nishio Y et al. (1995) Impaired activation of glucose oxidation and NADPH supply in human endothelial cells exposed to $\mathrm{H} 2 \mathrm{O} 2$ in high-glucose medium. Diabetes 44: 520-526

113. Cameron NE, Cotter MA (1992) Impaired contraction and relaxation in aorta from streptozotocin-diabetic rats: role of polyol pathway. Diabetologia 35: 1011-1019

114. Tesfamariam B, Palacino JJ, Weisbrod RM, Cohen RA (1993) Aldose reductase inhibition restores endothelial cell function in diabetic rabbit aorta. J Cardiovasc Pharmacol 21: 205-211

115. Sakakibara F, Hotta N, Koh N, Sakamoto N (1993) Effects of high glucose concentrations and epalrestat on sorbitol and myo-inositol metabolism in cultured rabbit aortic smooth muscle cells. Diabetes 42: 1594-1600

116. Park JY, Ha SW, King GL (1999) The role of protein kinase $\mathrm{C}$ activation in the pathogenesis of diabetic vascular complications. Perit Dial Int 19[Suppl 2]: S222-227

117. Wolf BA, Williamson JR, Easom RA, Chang K, Sherman WR, Turk J (1991) Diacylglycerol accumulation and mi- crovascular abnormalities induced by elevated glucose levels. J Clin Invest 87: 31-38

118. Tesfamariam B, Brown ML, Cohen RA (1991) Elevated glucose impairs endothelium-dependent relaxation by activating protein kinase C. J Clin Invest 87: 1643-1648

119. Brownlee M, Cerami A, Vlassara H (1988) Advanced glycosylation end products in tissue and the biochemical basis of diabetic complications. N Engl J Med 318: $1315-1321$

120. Brownlee M, Vlassara H, Cerami A (1984) Nonenzymatic glycosylation and the pathogenesis of diabetic complications. Ann Intern Med 101: 527-537

121. Vlassara H, Brownlee M, Cerami A (1985) High-affinityreceptor-mediated uptake and degradation of glucosemodified proteins: a potential mechanism for the removal of senescent macromolecules. Proc Natl Acad Sci USA 82: 5588-5592

122. Radoff S, Vlassara H, Cerami A (1988) Characterization of a solubilized cell surface binding protein on macrophages specific for proteins modified nonenzymatically by advanced glycosylated end products. Arch Biochem Biophys 263: 418-423

123. Makita Z, Radoff S, Rayfield EJ et al. (1991) Advanced glycosylation end products in patients with diabetic nephropathy. N Engl J Med 325: 836-842

124. Bucala R, Tracey KJ, Cerami A (1991) Advanced glycosylation products quench nitric oxide and mediate defective endothelium-dependent vasodilatation in experimental diabetes. J Clin Invest 87: 432-438

125. Hogan M, Cerami A, Bucala R (1992) Advanced glycosylation endproducts block the antiproliferative effect of nitric oxide. Role in the vascular and renal complications of diabetes mellitus. J Clin Invest 90: 1110-1115

126. Edelstein D, Brownlee M (1992) Aminoguanidine ameliorates albuminuria in diabetic hypertensive rats. Diabetologia 35: 96-97

127. Soulis T, Cooper ME, Vranes D, Bucala R, Jerums G (1996) Effects of aminoguanidine in preventing experimental diabetic nephropathy are related to the duration of treatment. Kidney Int 50: 627-634 